\title{
Beyond Geodiversity Sites: Exploring the Educational Potential of Widespread Geological Features (Rocks, Minerals and Fossils)
}

\author{
Paweł Wolniewicz ${ }^{1}$ \\ Received: 27 November 2020 / Accepted: 24 March 2021 / Published online: 5 April 2021 \\ (C) The Author(s) 2021
}

\begin{abstract}
Geosite and geodiversity site inventories are among the most important means of geological diversity conservation and promotion. However, there are other in situ geological features that have significant educational potential and are not included in many inventories, namely, localities of widespread rock types, common minerals and fossil-bearing strata. In this paper, a broad utilisation of these petrographic, mineralogical and palaeontological geodiversity elements for geoscience communication purposes is postulated, with a case study that focuses on the geological heritage of Poland. A simple quantitative framework for the evaluation of the educational potential of rock types is used for the assessment of preselected geological units on the geological map of Poland. The preferences of potential geotourists are estimated using the interactive web-based map. The promotional materials are written for the most distinctive rock types and geological units that scored the highest in the assessment procedure and/or were most frequently selected by users. This procedure stimulates geodiversity promotion in areas where few geosites and geodiversity sites are documented and no educational activities or interpretative facilities are available, potentially increasing the number of geotourism destinations. The rocks and minerals utilised here are exposed over large areas and can be sampled and studied by untrained collectors without any loss of geodiversity. Shifting the involvement of individuals interested in geosciences from extraordinary to more common rocky outcrops helps to protect the geological heritage and enhances conservation of the most spectacular features for future generations. Field activities such as individual searching and studying outcrops, in turn, play an important role in learning in geosciences, facilitating the acquisition of knowledge and encouraging interdisciplinary thinking. Future improvements could include expanding the applicability of the evaluation method, employment of a location-based learning approach \#and more detailed studies of the preferences of potential geotourists.
\end{abstract}

Keywords Geodiversity elements · Geodiversity evaluation · Scientific communication · Geo-education

\section{Introduction}

Geosites and geodiversity sites are in situ occurrences of geodiversity elements which provide scientific and educational value, respectively (for definitions, see Brilha 2016), and are considered as deserving geoconservation measures (Brocx and Semeniuk 2007; de Lima et al. 2010; Gordon 2019). Although the term geosite (geodiversity site) can be applied to vast areas of geological interest, such as whole outcrops and reserves (ProGEO 2011), in most cases, it is attributed to individual geological objects and particular localities that

Paweł Wolniewicz

pawelw@amu.edu.pl

1 Institute of Geology, Adam Mickiewicz University, Bogumiła Krygowskiego 12, PL-61-680 Poznań, Poland can be easily managed, with the exception of larger landforms and/or geomorphosites. This facilitates geodiversity protection but concentrates geotouristic interest on specific, often unique geological structures, which can lead to their degradation. Moreover, this usually excludes vast areas of the geological heritage pool that are less interesting for potential geotourists, being located outside geoparks and other protected areas or having not yet been assessed. Another implication is that geosites and geodiversity sites can be perceived as tourist attractions that are not spatially related to one another, hampering the possibility of understanding the broader context of geological structure and impoverishing geological field education by limiting it to a "standard" set of geosites (van Loon 2008). On the other hand, judging from the author's experience in maintaining a geo-educational website (zywaplaneta.pl, in Polish, available online since 2011), most visitors' inquiries are not related to particular 
geosites and geodiversity sites but to widespread rock types, minerals and fossils that are accidentally or purposefully found by amateur collectors in their vicinity or during holidays. This genuine interest in petrographic, mineralogical and palaeontological in situ geodiversity elements is largely unexploited within the framework of standard, preselected geosites and tourist attractions. Thus, there is an urgent need for comprehensive educational efforts to promote geological features beyond well-documented sites.

In this conceptual work, a broader utilisation of the educational potential of geodiversity elements such as outcrops of widespread rock types that are not protected or included in geosite inventories and can be studied by individual geotourists is postulated, with a case study that focuses on the geological diversity of Poland. A set of distinct rock types that have significant educational potential (mostly easily distinguishable rocks with many accessible outcrops across the country) is identified. These geodiversity elements can be collected by any individual if good sampling practices are followed, thereby enhancing the possibility of performing fieldwork and other informal educational activities; they are utilised to disseminate knowledge of geological history and the basic features of minerals and rocks.

On a limited scale, widespread rock types and other geodiversity elements are already being utilised in outdoor exhibits such as rock gardens to educate the community about the importance of local geology (Elmi et al. 2020) and to summarise the geological heritage of urban areas (Moliner and Mampel 2019). They frequently serve as an extension to an indoor museum or are used to offer workshops and guided tours to involve the general public. For lists of selected rock gardens, see Waldron et al. (2016) and Moliner and Mampel (2019).

\section{Geological Setting}

The territory of Poland is located at the junction of distinct geological and geomorphological units (Fig. 1a). The structural heterogeneity results in a significant variety of exposed rock types. Northern and central regions of the country belong to the East European Platform (north-eastern part) and Palaeozoic Platform of Western Europe (south-western part) and were covered by Pleistocene ice sheets that shaped the landscape of this area (Słomka 2008). Numerous rock types derived from the Scandinavian Peninsula, the bottom of the Baltic Sea and Finland and Estonia were transported within the ice sheets and deposited in tills and fluvioglacial gravels and sands.

Pre-Quaternary rocks are mainly exposed in southern Poland (Fig. 1b). Its south-western part (the Sudety Mountains and the Sudetic Foreland) is a Variscan orogen which mostly comprises folded and metamorphosed
Palaeozoic rocks that have been uplifted along the Sudetic Marginal Fault (Badura et al. 2004). These rocks are intruded by the Carboniferous granitoids and unconformably overlain by the Carboniferous to Permian sedimentary-volcanic sequences and the Triassic to Cretaceous sedimentary cover. In the Polish Uplands, Caledonian and Variscan fold belts are only partially exposed, being otherwise covered by Permian to Neogene sediments that were uplifted during the Alpine orogeny (Słomka 2008). Sedimentary rocks (Cambrian to Neogene in age) predominate, with subordinate Carboniferous and Permian volcanic units. The southern fringes of Poland are occupied by the Carpathians that represent the part of the Alpine orogenic belt and are composed predominantly of flysch and other sedimentary rocks, folded and thrusted over the Fore-Carpathian Depression. The names of geological units used in the present work follow Warowna et al. (2013), while the division of geographical regions of Poland is based on Solon et al. (2018).

\section{Methods}

Although the criteria for evaluating geosites and geodiversity sites are well defined (Reynard et al. 2007; Kubalíková 2013; Tomić and Božić 2014; Brilha 2016; Reynard et al. 2016), and the methodology for qualitative evaluation of interpretative resources has been developed (Sanz et al. 2020), no framework for quantitative assessment of the educational potential of rock types has been proposed before. A simple approach to the evaluation of common rock types for the purpose of promoting geodiversity is, therefore, introduced in this study. The selection, assessment and promotion of rocks are performed in the following steps:

1. Preselection of rock types

2. Preselection of glacial erratics

3. Numerical evaluation of educational value

4. Estimation of the public's demand

5. Scientific communication

\section{Preselection of Rock Types}

The initial list of rocks that are exposed in Poland were retrieved from the 1:500,000 scale geological map of Poland, published by the Polish Geological Institute (Marks et al. 2006) and available via the open government data platform (https://dane.gov.pl/pl/dataset/772,mapa-geologiczna-polskiw-skali-1500-000), to ensure the transparency of the preliminary selection procedure. For discussion on the objectivity of the preselection process in the geodiversity assessment, see Reynard et al. (2016). The map allowed us to define the geological framework of the study area prior to 
Fig. 1 Geological framework of the study area. a Main geological units of Poland. b Pre-Quaternary rocks exposed in Poland and the extent of the Pleistocene glaciations. 1, Sudety Mountains and Sudetic Foreland; 2, Fore-Sudetic Monocline; 3, Silesia Upland; 4, Kraków-Częstochowa Upland; 5, Małopolska Upland; 6, Holy Cross Mountains; 7, Lublin Upland; 8, Tatra and Pieniny Mountains
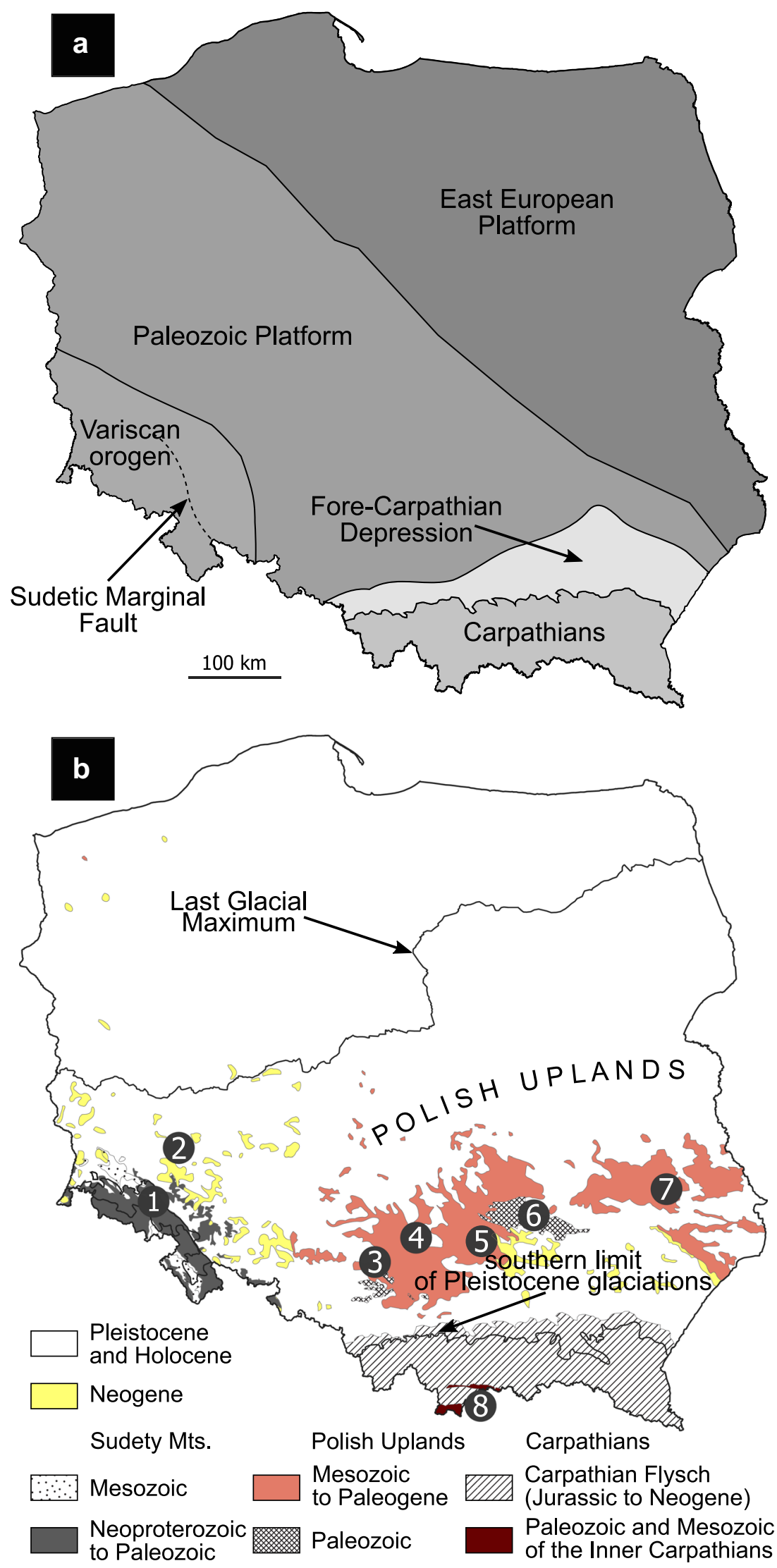
the evaluation process which, according to de Lima et al. (2010), is important when large areas are involved, particularly on a state-wide scale. The procedure guaranteed that the initial list of rock types was representative of the study area.

Geological units that refer to glacial landscape features (e.g. kame, esker, sandur, moraine plateau) and Pleistocene to Holocene fluvial and lake deposits were excluded from the database at this initial stage. Sedimentary rocks that outcrop in the same area and were deposited during the same epoch (for Cenozoic) and the same period (for older rocks) were included under a single unit in the database. Similar types of magmatic and metamorphic rocks (i.e. different types of gneisses), which occur in the same area and would be difficult to distinguish by non-geologists, were merged into one type. For a complete list of rock types, including deleted and combined types, see Online resource 1.

\section{Preselection of Basic Types of Glacial Erratics}

The glacial landforms comprising gravel- to megagravel-rich sediments (Blair and McPherson 1999), namely, moraine plateaus, end moraines and eskers, that are included in the geological map of Poland but were omitted from the preselection stage were added to the database as a separate entity (tills, fluvioglacial gravels). These boulder- and block-sized clasts that are common in tills and gravels were mostly derived from the Scandinavian Peninsula and adjacent areas and then transported by the Pleistocene ice sheets. Glacial erratics represent a heterogeneous group of rocks. For educational purposes, they are one of the most distinct rock types and are widespread in Pleistocene glacial deposits across Poland; the easiest rock types to recognise by an untrained collector were selected from the lists assembled by Czubla et al. (2006) and Górska-Zabielska (2008). The selection process was subjective and based on earlier conversations between the author and amateur collectors visiting the Museum of the Earth Sciences in Poznań, Poland. Selected rock types are included in Table 1 and in Fig. 2.

\section{Numerical Evaluation of Educational Value}

A parametric method for the evaluation of the educational potential of petrographic geodiversity elements is developed in this paper. The criteria used here partly follow those proposed for geomorphosite assessment by Bruschi et al. (2011) and are listed in Table 2 with the justification for their use.

$T s, N p, L p$, and $A p$ values (Table 2) were calculated in QGIS software using the open data sets regarding national parks, nature reserves and landscape parks in Poland from the Geoserwis repository (https://www.gdos.gov.pl/accessto-geospatial-data). Scores of the binary parameters $B s$ and $D s$ were obtained by the author through queries in existing publications. $G c$ was estimated using the list of geological concepts from the Earth Science Literacy Principles (Wysession et al. 2012); for each rock type, a list of geological phenomena and processes that can be interpreted from these rocks was compiled by the author (Table 3 ).

The variable $N p$ is log-normally distributed (Shapiro-Wilk normality test for $N p$ returns $W=0.18467, p$ value $=1.372 \mathrm{e}$ 15 ; for $\ln (N p) W=0.96983, p$ value $=0.1986)$. The natural logarithms of $N p$ values were thus used and scaled to the range between 0 and 100:

$N p_{\text {norm }}=\frac{\ln N p-m i n_{\ln N p}}{\max _{\ln N p}-\min _{\ln N p}} * 100$

$G c$ is an ordinal variable and is normalised between 0 and 100:

$G c_{\text {norm }}=\frac{G c-\min _{\mathrm{Gc}}}{\max _{\mathrm{Gc}}-\min _{\mathrm{Gc}}} * 100$

The parameters listed in Table 2 and derived from Eqs. (1) and (2) are integrated in the rock type educational value index $(R t)$, introduced here and expressed as:

$$
\begin{aligned}
R t= & \left(N p_{\text {norm }} * 0.5\right)+(A p * 0.15) \\
& +\left[\left(B s+D s+G c_{\text {norm }}\right) * 0.3\right]+(L p * 0.05)
\end{aligned}
$$

$R t$ is obtained by a weighted average of its criteria and takes values between 0 and 100 per cent; higher values indicate a greater geo-educational potential. The weights in Eq. (3) are based on the relative importance of each factor (estimated by the author's judgement), with $N p$ regarded as being the most significant (because rock types exposed over wider areas are easier to be found by an untrained collector) and $B s+D s+G c$ as the second most important (if a higher number of geological processes are interpretable from the rock, this increases its educational potential; the use of rock as a building or decorative stone facilitates its utilisation in geotourism). $A p$ is considered as less important, because outcrops of anthropogenic origin located in densely populated areas can potentially be utilised for geo-educational purposes. $L p$ is the least important parameter and receives the lowest weight: it is related to the nature conservation categories of Poland (Badora 2014), and its usage in other countries will require the expressions to be revised.

\section{Estimation of the Public's Demand}

A study of preferences from the general public should accompany the expert evaluation and numerical assessment of geosites (Božić and Tomić 2015; Różycka and Migoń 2018; Štrba 2019). To measure the level of interest among geotourists in geological units and rock types selected during the earlier stages of the research, an interactive geological map of Poland was used. The map, based on OpenStreetMap.org 
Table 1 List of geological units and rock types preselected from the 1:500,000 scale geological map of Poland

Number Age General rock types and geological units derived from the geological map of Poland

Sedimentary rocks

$1 \quad$ Pleistocene
Tills, fluvioglacial gravels (moraine plateaus, end moraines, eskers, kames)

Glacial erratics:

- Basalts from Skåne (southern Sweden)

- Granites from Dalarna (central Sweden) and Småland (southeastern Sweden)

- "Porphyries" from Baltic Sea bottom, Dalarna, and Småland

- Dalarna/Jotnian/Kalmar sandstones

- Silurian carbonates from Gotland, Sweden (with brachiopods, corals, crinoids, nautiloids and trilobites)

- Jurassic and Cretaceous flints from Baltic Sea bottom and northern Poland

Loess

Clays, silts and sands

Sands and silts with lignite

Limestones and gypsum of the Fore-Carpathian Depression

Sands with amber, silts, clays

Podhale flysch (shales, mudstones, sandstones)

Nummulitic limestones of the Tatra Mts.

Gaizes, limestones and glauconitic sands of the Lublin Upland

Carpathian flysch

Sandstones and marls of the Sudety Mts.

Limestones and sandstones with cherts, marls, phosphorites, gaizes

Cieszyn limestones and shales

Sedimentary rocks of the Pieniny Mts. (limestones, cherty limestones, radiolarites, sandstones)

Limestones with ammonites and sponge bioherms

Limestones, marls, claystones with siderites

Continental and coastal sandstones and mudstones with dinosaur traces

Fluvial sandstones, gypsum-rich mudstones and claystones, with vertebrate remains

Organodetritic limestones and dolomites

Red sandstones, conglomerates and claystones

Mesozoic sedimentary rocks of the Tatra Mts. (sandstones, shales, limestones, dolomite, radiolarites and marls)

Red conglomerates, sandstones and mudstones of the Holy Cross Mts., with gypsum and halite

Red sandstones, mudstones, limestones and dolomite, with gypsum and halite

Continental deposits of the Kraków area (conglomerates, arkose sandstones)

Hard coal, sandstones and mudstones

Greywackes, conglomerates and limestones of the Holy Cross Mts.

Devonian limestones and sandstones of the Holy Cross Mts. and Kraków area

Graptolithic claystones and siliceous shales

Graptolithic shales and sandstones of the Sudety Mts.

Sandstones and limestones of the Holy Cross Mountains

Dolomites, limestones and shales of the Sudety Mts.

Quartz sandstones and mudstones of the Holy Cross Mts.

Lusatian greywackes

Cambrian

Ediacaran

Sedimentary rocks with subordinate volcanics and greenstones

34 Carboniferous

35 Devonian-Carboniferous

36 Devonian-Carboniferous

Igneous rocks

$\begin{array}{ll}37 & \text { Neogene } \\ 38 & \text { Oligocene-Pliocene } \\ 39 & \text { Cretaceous }\end{array}$

Conglomerates, sandstones, mudstones and rhyolites

Conglomerates, greywackes, limestones, with subordinate rhyolites and greenstones

Fanglomerates, olistostrome deposits, conglomerates, mudstones and greenstones

Andesites of the Pieniny Mts.

Lower Silesian Cenozoic basaltoids

Teschenites 
Table 1 (continued)

\begin{tabular}{lll}
\hline Number & Age & General rock types and geological units derived from the geological map of Poland \\
\hline 40 & Carboniferous-Permian & Rhyolites, rhyodacite, trachybasalts and trachites \\
41 & Carboniferous & Variscan granitoids (granites, monzogranites and granodiorites) \\
42 & Silurian-Devonian & Gabbros \\
43 & Cambrian-Ordovician & Cadomian granites (with orthogneisses) \\
44 & Ediacaran-Cambrian & Lusatian granodiorites \\
Metamorphic rocks & \\
45 & Carboniferous & Cataclasites and tectonic breccias \\
46 & Devonian & Quartzites and quartzite shales \\
47 & Silurian-Devonian & Serpentinites and peridotites \\
48 & Ordovician-Carboniferous & Phyllites, shales and siliceous shales \\
49 & Ordovician-Devonian & Greenstones and greenstone schists \\
50 & Cambrian-Ordovician & Gneisses, migmatites and amphibolites of the Owl Mts. and Śnieżnik Mts. \\
51 & Cambrian-Ordovician & Granulites and eclogites \\
52 & Cambrian-Devonian & Gneisses, migmatites, amphibolites of the Tatra Mts. \\
53 & Ediacaran-Ordovician & Mica schists, marbles and leptinites \\
\hline
\end{tabular}

data and JavaScript library Leaflet.js, records the coordinates of the mouse clicks made by anonymous users, with the number of clicks per rock type and per square kilometre of rock exposure being calculated. Clicks on the exposures of geological units preselected in the first stage open a new window in which the photographs and descriptions of the corresponding rock types are shown (Fig. 3).

The interactive map has been available from January 2020 at https://zywaplaneta.pl/mapa-geologiczna-polski/, on the geo-educational website zywaplaneta.pl, created and maintained by the author. The geographical coordinates of mouse clicks were counted between January and July 2020 . The website currently attracts approximately 22,000 unique visitors per month (measured from January 2020 to June 2020); the readers that communicated with the author described themselves as teachers, students, parents of children interested in geosciences and amateur collectors. Pages that contain the lists of geological museums, caves opened for tourists, underground routes and dinosaur parks are among the most popular pages on the website, which confirms its usefulness for investigating the preferences of amateurs interested in geosciences. According to Štrba (2019), most geotourists search for the information on geosites on the Internet; thus online communication channels are perceived to be the most appropriate for studying their demands.

\section{Promotion and Scientific Communication}

The information on the geological units and rock types that scored highest and are included in the final list, considered here as having the best potential for educative activities, has been communicated to the public using both online and face- to-face channels. Detailed index cards on each rock type have been included in the interactive geological map of Poland. A short, 78-page e-book that aims at teaching the features of minerals and principles for the recognition of rocks, with references to the corresponding rock types from the database, is also published (in Polish), together with short explanations on how the rocks involved in the project were formed and how their history is related to the geological history of Europe and the Earth as a whole. Educational workshops for children, covering the topics related to the most common rock types found in glacial and fluvioglacial deposits and Polish rocks and fossils, were organised by the Museum of Earth Sciences in Poznań.

Digital content relating to the project under study has been published at the zywaplaneta.pl website between March 2015 and May 2020. Twelve web pages were viewed 3650 times per month (data for the period from January to June 2020). A PDF file that contains e-book and supplemental material has been downloaded 242 times during the same period. Educational workshops held at the Museum of the Earth Sciences in Poznań, between 2015 and 2019, were attended by over 300 participants.

\section{Results}

One hundred thirty-five geological and landscape units of the geological map of Poland were reduced to 53 basic items during the preselection stage. Twenty-six sediment types and landforms associated with Pleistocene and Holocene sediments (except for the megagravel-rich and loess deposits included on the list as separate units) were removed from the 
Fig. 2 Most distinct glacial erratics that are widespread in Pleistocene glacial deposits of Poland, selected for the study. Scale bars equal $5 \mathrm{~cm}$. a Skåne basalt. b Småland granite. c "Porphyry". d Dalarna/Jotnian sandstone. e Silurian limestone with brachiopods. f Mesozoic flint with belemnite
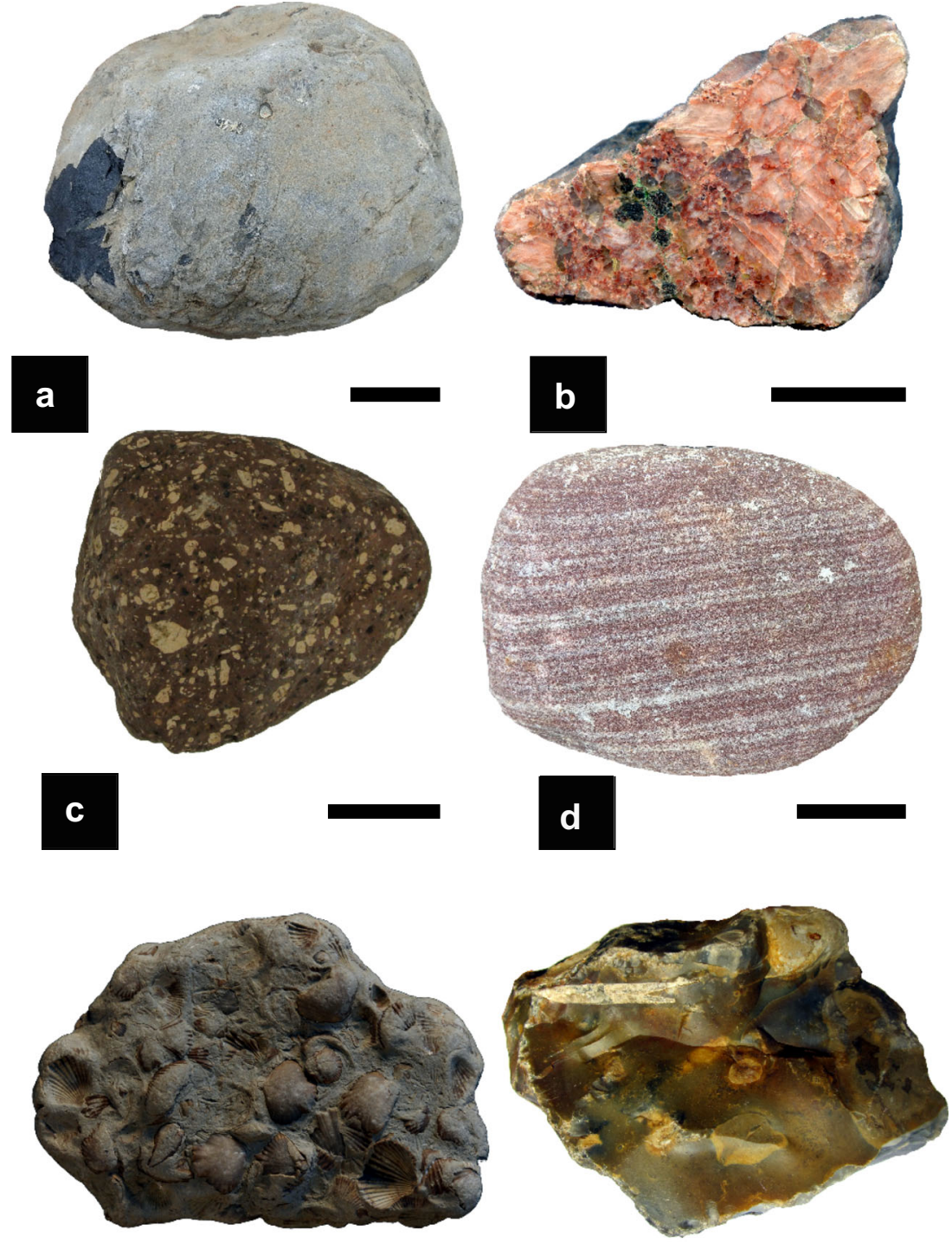

e

\section{c}

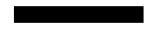

d database, while the other 109 rock types and geological units were aggregated into 52 units (Online resource 1). Within tills and fluvioglacial gravels of moraine plateaus, end moraines and eskers, six basic groups of erratic rocks of Scandinavian origin were selected by the author. The rock types included in the database have abundant and accessible outcrops scattered over an area of $164,469 \mathrm{~km}^{2}$, covering $52.61 \%$ of the total area of Poland.

In the subsequent step of the study, $R t$ was obtained for preselected rock types, and 15 rock types that scored the highest $R t$ values (higher than 60 per cent) were chosen for further educational efforts (Table 4 and Fig. 4; for details on the calculation of $R t$, see Online resource 2). Outcrops of selected rocks and geological units cover $50.01 \%$ of the territory of Poland $\left(156,367 \mathrm{~km}^{2}\right)$.
The estimations of general public preferences obtained from the digital geological map of Poland are summarised in Table 4. The interactive map has been actively used by 1504 unique visitors, generating 8917 clicks. Hard coal, sandstones and mudstones (geological unit no. 25); Cadomian granites/ orthogneisses (43); and phyllites (48) received $R t$ scores less than $60 \%$ but were clicked on more than one hundred times. They were, therefore, added to the list of selected rock types. This expanded the area of exposures of the 18 selected rock types to $158,181 \mathrm{~km}^{2}$ and $50.59 \%$ of the country's area (Figs. 5 and 6).

The largest number of clicks per unit area were recorded on rocks exposed over small areas, mostly within national parks and reserves (e.g. in the Tatra and Pieniny Mountains), but the total number of clicks on their outcrops did not exceed 40 . 
Table 2 Criteria for evaluating the geo-educational potential of rock types outcropping in Poland

\begin{tabular}{|c|c|c|}
\hline & Criterion & Rationale \\
\hline$T s$ & $\begin{array}{l}\text { Total surface area of geological units and/or ex- } \\
\text { posures (in } \mathrm{km}^{2} \text { ) }\end{array}$ & $\begin{array}{l}\text { The highest geo-educational potential is exhibited } \\
\text { by rocks that crop out over a significant area. } \\
\text { This increases the number of natural exposures } \\
\text { and enables sampling without significant loss of } \\
\text { geodiversity }\end{array}$ \\
\hline$N p$ & $\begin{array}{l}\text { Percentage of rock type surface area located } \\
\text { outside existing reserves and national parks } \\
(0-100 \%)\end{array}$ & $\begin{array}{l}\text { Outcrops within national parks and reserves, which } \\
\text { cover ca. } 3.5 \% \text { of the country area (Badora } \\
\text { 2014), are not suitable for geo-educational } \\
\text { purposes, because the sampling and collecting of } \\
\text { rocks, even for educational and private use, is } \\
\text { prohibited in most cases }\end{array}$ \\
\hline$L p$ & $\begin{array}{l}\text { Percentage of exposure area located within } \\
\text { landscape parks and protected landscape areas } \\
(0-100 \%)\end{array}$ & $\begin{array}{l}\text { Landscape parks and protected landscape areas } \\
\text { account for ca. } 30 \% \text { of the total country area (for } \\
\text { a discussion on these nature conservation } \\
\text { categories in Poland, see Badora 2014). The ac- } \\
\text { cess to outcrops is not limited there, rock sam- } \\
\text { pling for private use is allowed, and high land- } \\
\text { scape value improves the geo-educational po- } \\
\text { tential of natural exposures }\end{array}$ \\
\hline$A p$ & $\begin{array}{l}\text { Percentage of exposure area located outside } \\
\text { densely populated areas, i.e. outside the } \\
\text { boundaries of towns }\end{array}$ & $\begin{array}{l}\text { Natural rock exposures are rare and poor within } \\
\text { urban areas in most cases, offering a limited } \\
\text { availability of field work activities. Outcrops } \\
\text { located in densely populated areas are excluded } \\
\text { in the evaluation }\end{array}$ \\
\hline$G c$ & $\begin{array}{l}\text { Number of geological and/or geomorphological } \\
\text { processes and concepts that are clearly visible or } \\
\text { interpretable (ordinal variable) }\end{array}$ & $\begin{array}{l}\text { A list of geological concepts and processes is } \\
\text { extracted from the Earth Science Literacy } \\
\text { Principles (Wysession et al. 2012) and outlined } \\
\text { in Table 3. Rock types that allow studying many } \\
\text { geological concepts and processes exhibit higher } \\
\text { educational potential }\end{array}$ \\
\hline$B s$ & $\begin{array}{l}\text { Active exploitation for building and/or decorative } \\
\text { purposes (binary parameter) }\end{array}$ & $\begin{array}{l}\text { Rock can be seen outside its natural exposure, in } \\
\text { urban areas, as building and/or decorative stone. } \\
\text { Polished rock surfaces provide an important re- } \\
\text { source for education (Brocx and Semeniuk } \\
\text { 2019) and supplement natural occurrences of } \\
\text { rock with ex situ geodiversity elements. For rock } \\
\text { types not used for building and/or decorative } \\
\text { purposes, the value of this parameter is zero }\end{array}$ \\
\hline$D s$ & $\begin{array}{l}\text { Use as a decorative stone in historical times (binary } \\
\text { parameter) }\end{array}$ & $\begin{array}{l}\text { Rock type can be seen in historical monuments, } \\
\text { contributing to the promotion of geological } \\
\text { diversity among tourists who are interested } \\
\text { primarily in historical and cultural heritage }\end{array}$ \\
\hline
\end{tabular}

Therefore, these rocks were not included in the list of selected rock types.

Within the petrographic geodiversity elements that scored highest or were clicked $>100$ times, sedimentary rocks are represented most widely (12 rock types), followed by metamorphic (4) and then igneous (3); both igneous and sedimentary rocks appear in tills and fluvioglacial gravels. Sedimentary rocks include clastic rocks (9) and biochemical/ chemical rocks (7), with Devonian and Cretaceous deposits of the Polish Uplands, Carboniferous coal-bearing rocks and erratic boulders belonging to both categories. The age of the rocks ranged from the Mesoproterozoic (1), Palaeozoic (9) and Mesozoic (7) to the Cenozoic (4). Erratic boulders are most common in northern and central Poland, while other rock types can be found in the Sudety Mountains and the Sudety Foreland (8 rock types); the Małopolska Upland, including the Holy Cross Mountains (7); the Kraków-Częstochowa Upland (5); the Lublin Upland (2); the Silesia Upland (2); and the Carpathians (1); some rock types appear in more than one geographical region.

\section{Discussion}

The procedure described here accelerates the promotion of geodiversity in areas where few geosites/geodiversity sites 
Table 3 Geological phenomena explained by rock type/geological unit
Geological phenomena explained by rock type/ geological unit (after ESLP)
Rock types (number refers to rock type/geological unit number from Table 1)
Big Idea 2. Earth is 4.6 billion years old

2.1 Sequence of rocks and sediments

2.1 Structure and properties of rocks and sediments

2.1 Numerical ages of rocks

2.1 Events in Earth's history

2.4 Oceanic and continental crust

2.6 Fossils

2.7 Supercontinents

2.7 Ice sheets

Big Idea 3. Earth is a complex system of interacting rock, water, air and life

3.8 Changes to global and regional patterns of temperature and precipitation

Big Idea 4. Earth is continuously changing

4.3 Plate tectonics

4.3 Tectonic events

4.5 Plate boundaries

4.5 Locations of earthquakes and volcanoes

4.5 Mountain formation and erosion, location of mountain ranges

4.6 Magmatic processes, igneous rocks

4.6 Alteration of older rocks, metamorphic rocks

4.7 Weathering and erosion

4.8 Sediment transport

4.9 Sea level and shoreline changes

Big Idea 5. Earth is the water planet

5.5 Global ocean circulation

5.6 Water-, wind- and ice-shaped landscapes

5.6 Water as transport agent

5.7 Ice Ages

5.7 Frost weathering

Big Idea 6. Life evolves on a dynamic Earth and continuously modifies Earth

6.2 Evolution and extinctions

6.6 Mass extinctions

6.8 Fossil record as a means for understanding the history of Earth's geosphere

Big Idea 7. Humans depend on Earth for resources

7.3 Non-renewable natural resources

7.4 Unevenly distributed resources

7.9 Fossil fuels

Big Idea 8. Natural hazards pose risks to humans

8.1 Volcanic eruptions

8.1 Floods, landslides, coastal erosion, subsidence

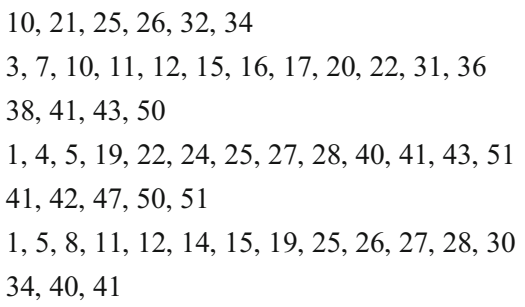

$22,27,33,35,40,41,42,43,47,50,51$

$22,24,25,33,34,35,36,37,40,41,43,45,48,50$, $51,52,53$

$41,42,43,51$

$37,38,40$

$20,21,22,23,24,25,34,40,41,44,45,51$

$1,24,37,38,39,40,41,42,43,44,50$

$21,43,45,46,47,48,49,50,51,53$

$2,7,20,22,24$

$1,20,33,36$

$5,6,9,11,12,15,16,17,19,21,23,26,27,28,29$

$12,14,15,23$

$1,2,20$

$1,2,4,7,9,10,11,13,14,16,17,18,22,25,32$

1,2

1,32

$12,15,18,27$

$12,22,24$

$4,12,14,15,17,18,19,21,27,28$

$16,19,23,25$

$4,23,25$

4,25

$24,37,38,40$

10

Number of geological concepts refers to the list of Earth Science Literacy Principles (ESLP, Wysession et al. 2012)

are documented and educational activities or interpretative facilities are not available. It invites the participants of the project to perform individual fieldwork and to explore geodiversity elements in their direct surroundings. However,
Newsome and Dowling (2006) established a hierarchical order of geological and geomorphological features of geotouristic interest, with rocks and sediments described as less attractive. This confirms the importance of spectacular 


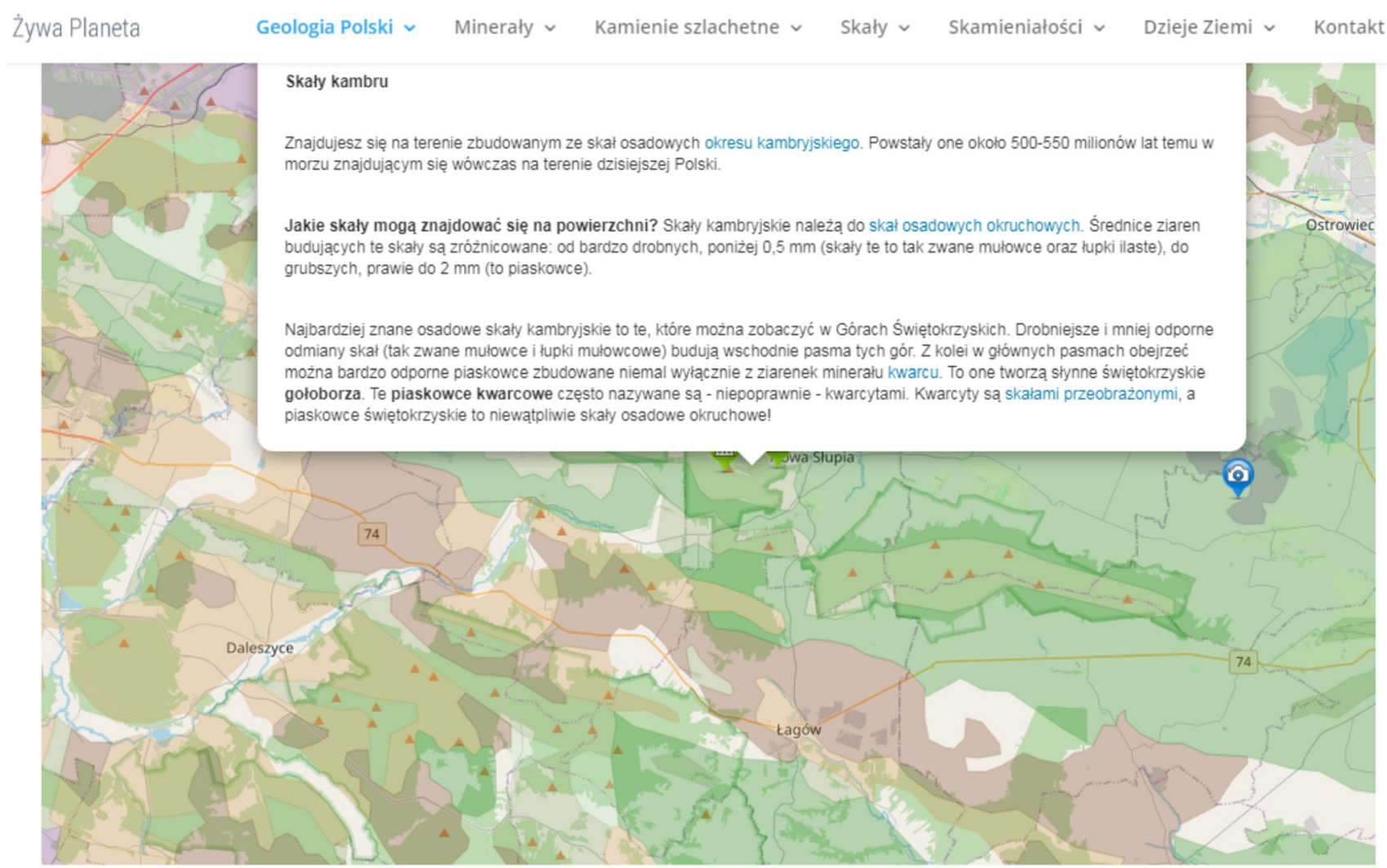

Fig. 3 Screenshot showing a part of the interactive geological map of Poland, which is used for the estimation of general public preferences

geosites and geosite inventories as a means of geoheritage promotion. According to Ruban and Kuo (2010), a special impulse is needed to appreciate natural features such as minerals, rocks and fossils, and finding such items in the vicinity or during recreational activities may be such a stimulus. Memorable experiences related to geodiversity have the potential of connecting people to geoheritage and increasing support for geoconservation (Ruban and Kuo 2010). The educational activities not related to geosites disperse the geotouristic traffic, supporting protection of spectacular geosites and preserving geological features for future research. Most geological resources are non-renewable; this also applies to geological features which, once altered or destroyed, are unlikely to recover. Standard geodiversity sites can be damaged by untrained collectors hunting for fossils and minerals. The method introduced here has the potential of reducing the number of visitors to geosites, directing the interest of the public to local outcrops and geodiversity sites, reducing the environmental impact of geotourist activity and fostering the sustainable use of natural resources. The petrographic geodiversity elements used in this study are common and widespread and can, therefore, tolerate higher levels of educational use. Obtaining a fresh surface of rock or studying a fossil in three dimensions is important for educational purposes and helps people to grasp many geological concepts that foster greater understanding of geological processes. To enable people to target outcrops where such actions are acceptable and have no negative impact on site's scientific and aesthetic value helps amateurs in the understanding of geological processes. This is particularly evident in the case of rocks and fossils from glacial sediments. These are thrown out from their stratigraphic context and are sufficiently abundant to allow non-scientific collecting. Scientific provenance analysis of glacial erratics requires the study of a significant number of specimens from a single site; therefore sampling for personal use will not prejudice future research. The same applies to fossils from glacial deposits, which can be assigned to category 4 in the classification scheme described by Page (2003), i.e. the least necessary to protect.

The Pre-Quaternary rocks selected from central and southern Poland are more problematic. They are widely distributed and easily accessible and can be economically exploited without any significant loss of geodiversity. However, some of the exposures contain unique sedimentary structures or fossils that require in situ protection. The Lower Jurassic sandstone, in which dinosaur tracks are preserved (Gerliński et al. 2004), is a good example. Other geological sites with trace fossils can potentially be discovered by amateur collectors using the digital assets provided in this project, and the future of such exposures will depend on their awareness and good sampling practices. The resources available via the Internet that promote access to geosites can have a negative effect on their protection (Druguet et al. 2013). The issue is of great importance because geological resources available via the Internet are the 
Table 4 Results of the evaluation process and estimation of general public preferences

No. General rock types and geological units derived from the geological map of Poland (for $R t$ complete descriptions, see Table 1)
Number of Number of clicks per $400 \mathrm{~km}^{2}$ of clicks the exposure

\begin{tabular}{|c|c|c|c|c|}
\hline 1 & Tills, fluvioglacial gravels & 94.21 & 2470 & 8.64 \\
\hline 2 & Loess & 64.32 & 673 & 17.37 \\
\hline 3 & Neogene clays & 51.84 & 11 & 5.99 \\
\hline 4 & Neogene sands with lignite & 59.16 & 94 & 26.3 \\
\hline 5 & Limestones and gypsum of the Fore-Carpathian Depression & 72.29 & 69 & 23.22 \\
\hline 6 & Sands with amber & 38.79 & 10 & 63.73 \\
\hline 7 & Podhale flysch & 53.18 & 26 & 28.36 \\
\hline 8 & Nummulitic limestones & 23.46 & 1 & 46.1 \\
\hline 9 & Gaizes, limestones and glauconitic sands & 48.84 & 26 & 25.99 \\
\hline 10 & Carpathian flysch & 80.78 & 607 & 18.26 \\
\hline 11 & Sandstones and marls of the Sudety Mts. & 68.01 & 77 & 45.77 \\
\hline 12 & Cretaceous limestones with cherts and sandstones & 82.87 & 166 & 10.86 \\
\hline 13 & Cieszyn limestones and shales & 41.44 & 12 & 36.21 \\
\hline 14 & Sedimentary rocks of the Pieniny Mts. & 50.25 & 14 & 60.7 \\
\hline 15 & Jurassic limestones with ammonites and sponges & 75.32 & 216 & 69.68 \\
\hline 16 & Jurassic limestones and claystones with siderites & 51.55 & 31 & 33 \\
\hline 17 & Jurassic sandstones with dinosaur traces & 71.94 & 43 & 16.06 \\
\hline 18 & Triassic sandstones and claystones with vertebrate remains & 53.05 & 41 & 36.35 \\
\hline 19 & Triassic organodetritic limestones and dolomites & 69.67 & 116 & 56.42 \\
\hline 20 & Triassic sandstones, conglomerates and claystones & 74.01 & 88 & 57.95 \\
\hline 21 & Mesozoic sedimentary rocks of the Tatra Mts. & 20.00 & 41 & 214.92 \\
\hline 22 & Permian conglomerates of the Holy Cross Mts. & 57.63 & 5 & 99.68 \\
\hline 23 & Permian sandstones, mudstones, limestones and dolomites & 55.29 & 70 & 53.42 \\
\hline 24 & Continental deposits of the Kraków area & 54.79 & 17 & 272.77 \\
\hline 25 & Hard coal, Carboniferous sandstones and mudstones & 58.64 & 100 & 90.17 \\
\hline 26 & Carboniferous conglomerates and limestones of the Holy Cross Mts. & 39.07 & 5 & 199.37 \\
\hline 27 & Devonian limestones and sandstones of the Holy Cross Mts. and Kraków area & 72.46 & 127 & 120.34 \\
\hline 28 & Graptolithic shales & 50.38 & 22 & 59.51 \\
\hline 29 & Graptolithic shales and sandstones of the Sudety Mts. & 28.45 & 0 & 0 \\
\hline 30 & Ordovician sandstones and limestones & 36.60 & 4 & 208.01 \\
\hline 31 & Cambrian limestones and shales of the Sudety Mts. & 29.26 & 0 & 0 \\
\hline 32 & Cambrian sandstones and mudstones of the Holy Cross Mts. & 52.35 & 62 & 91.96 \\
\hline 33 & Lusatian greywackes & 34.56 & 3 & 91.92 \\
\hline 34 & Carboniferous conglomerates, sandstones, mudstones and rhyolites & 51.86 & 16 & 17.02 \\
\hline 35 & Conglomerates with subordinate rhyolites and greenstones & 43.85 & 4 & 20.31 \\
\hline 36 & Fanglomerates, olistostrome deposits and greenstones & 45.42 & 10 & 76.37 \\
\hline 37 & Andesites of the Pieniny Mts. & 46.36 & 7 & 992.81 \\
\hline 38 & Lower Silesian Cenozoic basaltoids & 45.73 & 25 & 121 \\
\hline 39 & Teschenites & 33.52 & 1 & 34.61 \\
\hline 40 & Rhyolites, rhyodacite, trachybasalts and trachites & 63.62 & 30 & 66.87 \\
\hline 41 & Variscan granitoids & 68.41 & 139 & 86.42 \\
\hline 42 & Gabbros & 50.14 & 13 & 216.59 \\
\hline 43 & Cadomian granites (with orthogneisses) & 59.94 & 109 & 57.09 \\
\hline 44 & Lusatian granodiorites & 37.66 & 3 & 34.24 \\
\hline 45 & Cataclasites and tectonic breccias & 38.41 & 1 & 80.27 \\
\hline 46 & Quartzites and quartzite shales & 37.39 & 4 & 54.37 \\
\hline 47 & Serpentinites and peridotites & 60.21 & 16 & 104.11 \\
\hline 48 & Phyllites, shales and siliceous shales & 49.88 & 101 & 66.58 \\
\hline
\end{tabular}


Table 4 (continued)

No. General rock types and geological units derived from the geological map of Poland (for $R t$ complete descriptions, see Table 1)
Number of Number of clicks per $400 \mathrm{~km}^{2}$ of clicks the exposure

\begin{tabular}{|c|c|c|c|}
\hline 49 & Greenstones and greenstone schists & $44.90 \quad 27$ & 57.19 \\
\hline 50 & Gneisses, migmatites and amphibolites of the Owl Mts. and Śnieżnik Mts. & 64.5089 & 63.09 \\
\hline 51 & Granulites and eclogites & 41.977 & 862.85 \\
\hline 52 & Gneisses, migmatites, amphibolites of the Tatra Mts. & 24.139 & 159.42 \\
\hline 53 & Mica schists, marbles and leptinites & $54.94 \quad 41$ & 65.06 \\
\hline
\end{tabular}

Rock types that scored the highest $R t$ values (higher than 60 per cent) and/or were clicked on the interactive map more than one hundred times and were chosen for further educational efforts are marked in bold

most effective media for promoting geotourism (Štrba 2019). Examples of severe land degradation caused by collectors of minerals and fossils are known from Poland, with welldocumented excavation holes in agate-bearing rhyolites and trachybasalts (geological unit no. 40 in Table 1; Migoń and Pijet-Migon 2020). The initiatives that aim to provide information about geological sites through the indication of the
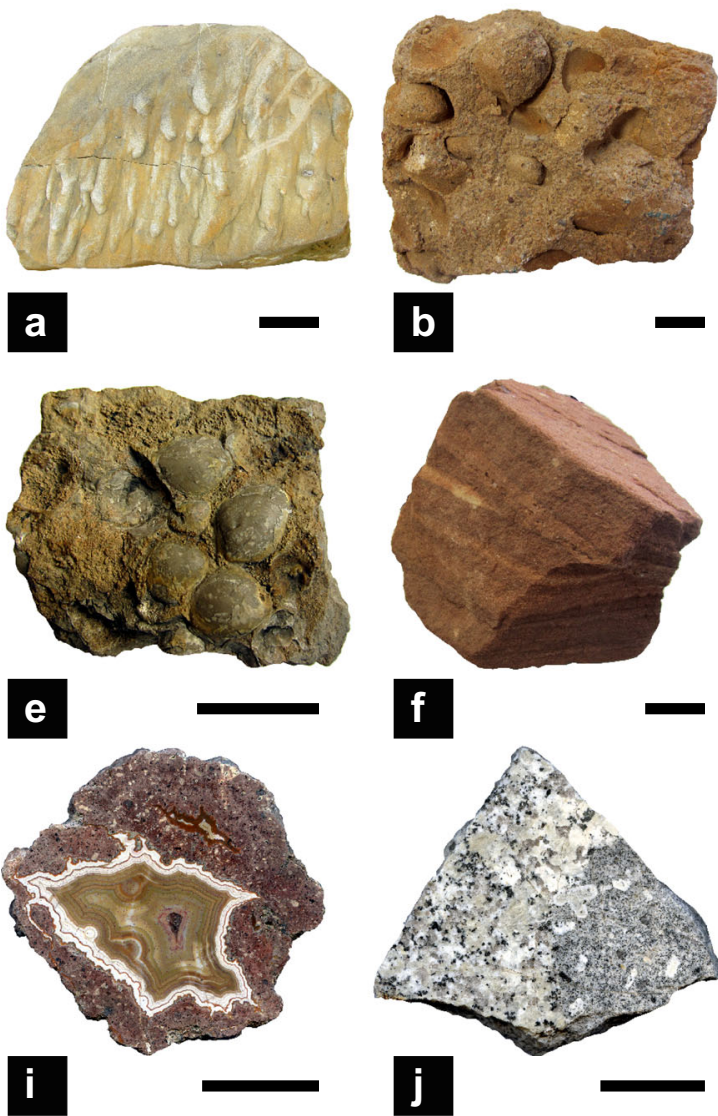

Fig. 4 Examples of rock types that scored highest during the evaluation and were chosen for further educational efforts. Scale bars equal $5 \mathrm{~cm}$. a Sandstone with flute marks seen as moulds (Carpathian flysch; geological unit no. 10). b Coarse sandstone from the Cretaceous of the Sudety Mountains, with cavities formed by dissolution of bivalve shells (11). $\mathbf{c}$ Cretaceous carbonate from the Małopolska Upland with a cast of gastropod shell (12). d Jurassic limestone with ammonite (15). e Middle precise outcrop positions, such as geosite inventories, or less precise general exposure location (as in the current project) could, therefore, lead to the loss of geodiversity. Earlier authors recommended that databases and promotional activities should be supplemented by advice and warning messages referring to good sampling practices (Druguet et al. 2013), limiting the risk of damage to outcrops. In the project under
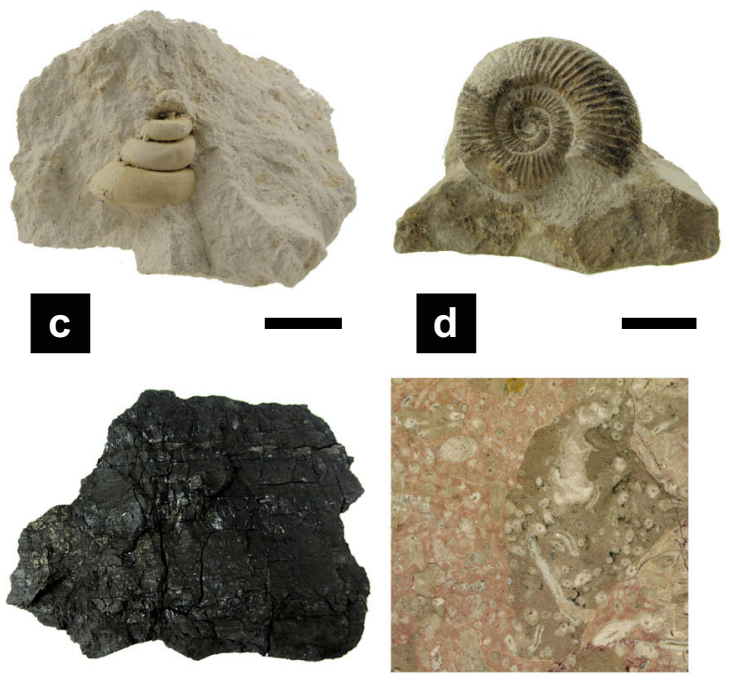

g

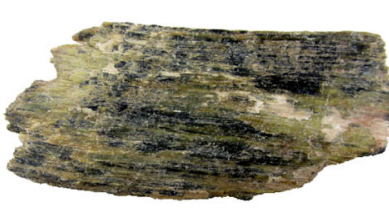

h

$\mathbf{k}$

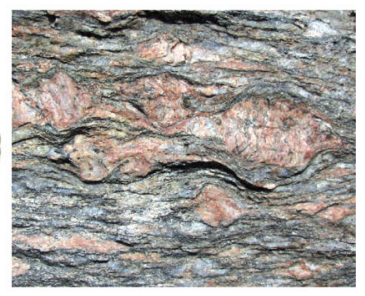

Triassic limestone with terebratulid brachiopods (19). f Red, crossbedded, aeolian sandstone from the Lower Triassic of the Holy Cross Mountains (20). g Hard coal from the Silesia Upland (25). h Devonian limestones of the Holy Cross Mountains with stromatoporoid sponges (27). i Rhyolite with agate, Sudety Mountains (40). j Variscan granitoid, Sudety Mountains and Sudetic Foreland (41). k Serpentinite (47). I Gneiss from the Orlica-Śnieżnik Dome, Sudety Mountains (50) 
Fig. 5 Exposures of the most widespread rock types and geological units selected in the evaluation process

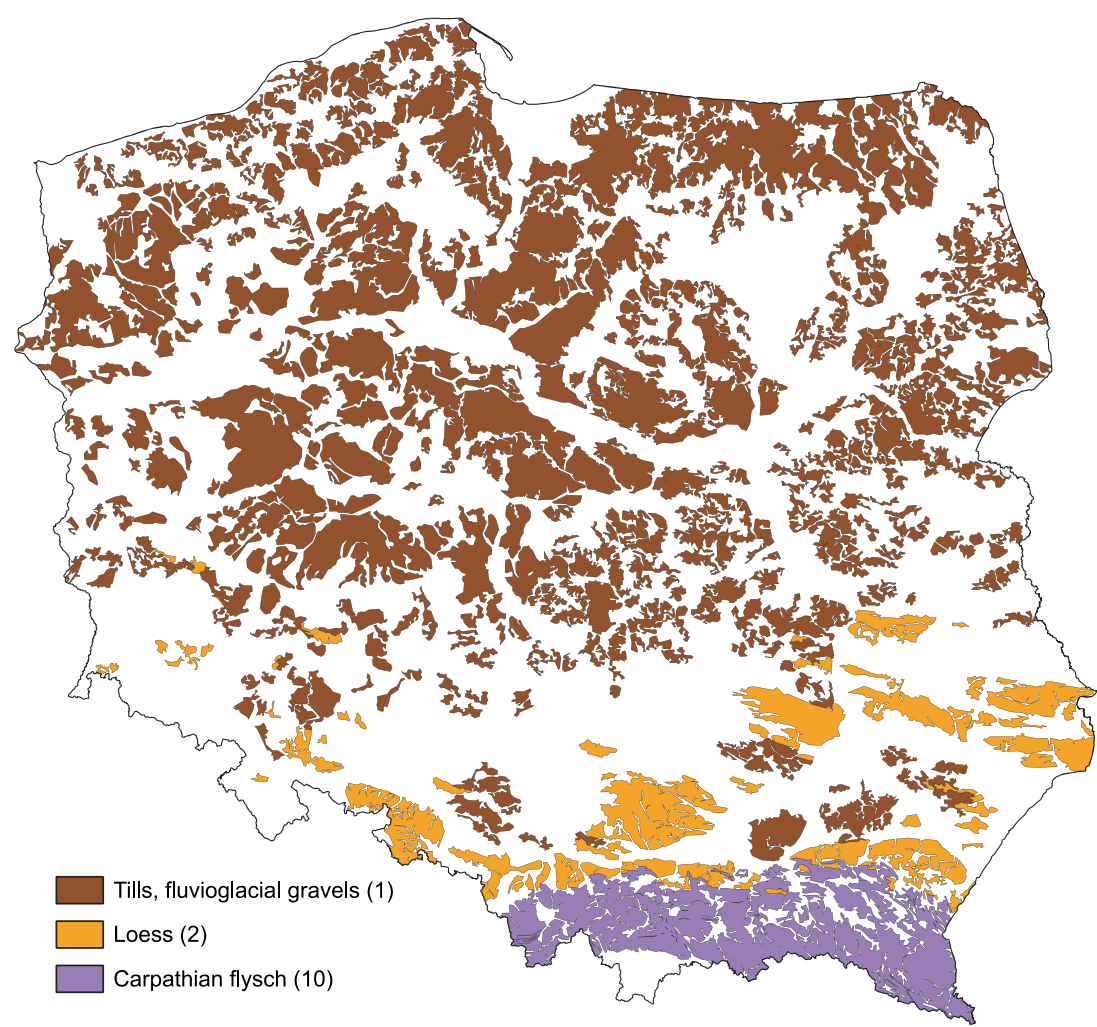

study, proper sampling practices are crucial, because geotourists search for geodiversity sites on their own. Therefore, they should be trained in legal and geoethical issues relating to fieldwork. To address that issue, the digital assets include an additional page on good sampling practices.

Shifting the emphasis from standard geosites, located within protected areas, to local exposures that are not included in geosite inventories could also stimulate landowner interest in geoconservation. In the traditional model of geotourism promotion, landowners do not intend to support geosite designation and geoconservation, being afraid that the protection will limit their rights on their land (Ruban and Kuo 2010). On the other hand, rocks and fossils are generally not protected in Poland except where they occur in national parks or natural reserves. Spectacular landforms and glacial erratics are protected by law as natural monuments, although the legal criteria are not clear, which causes the disappearance of erratic boulders from the landscape (Górska-Zabielska et al. 2020). In the project under study, rock exposures are not the subject of future protection initiatives, which is a common procedure in standard geoconservation.

Individual exploration of the geological setting of a neighbourhood is a form of learning through experience (experiential learning) which constitutes an effective approach to studying various geological phenomena, in particular when the general public is concerned (Moutinho and Almeida 2016). Orion (1993) believed that direct experience with material (e.g. rock types) and processes (e.g. related to the formation of glacial landforms) fosters memorisation and enhances the learning of abstract concepts. Field activities can, therefore, play an important role in learning in geosciences (Gomes et al. 2016). This applies to both formal and informal geo-education, underlining the importance of field education in geosciences and in communicating geodiversity. Earlier research stressed the role of outdoor learning and environmental interaction in facilitating the acquisition of knowledge and in fostering interdisciplinary thinking (Tan and So 2019). For example, boulder gardens and simulated field environments have proved useful in transferring classroom knowledge to fieldwork (Waldron et al. 2016). However, Gomes et al. (2016) noted the lack of support materials necessary for individuals and teachers that plan to engage with the outdoor environment. These problems were identified by trained teachers; thus they are even more compelling in informal education, where the role of an untrained parent or tutor is crucial. Most educational resources are prepared for protected areas and the most spectacular and most frequently visited geosites, whereas ordinary exposures are barely documented for educational purposes or for educators who aim to teach geosciences in their local environment. This project fills this gap by providing material for the whole of Poland.

\section{Assessment Procedure}

The evaluation method used to assess the geo-educational potential of common rock types is relatively objective and 

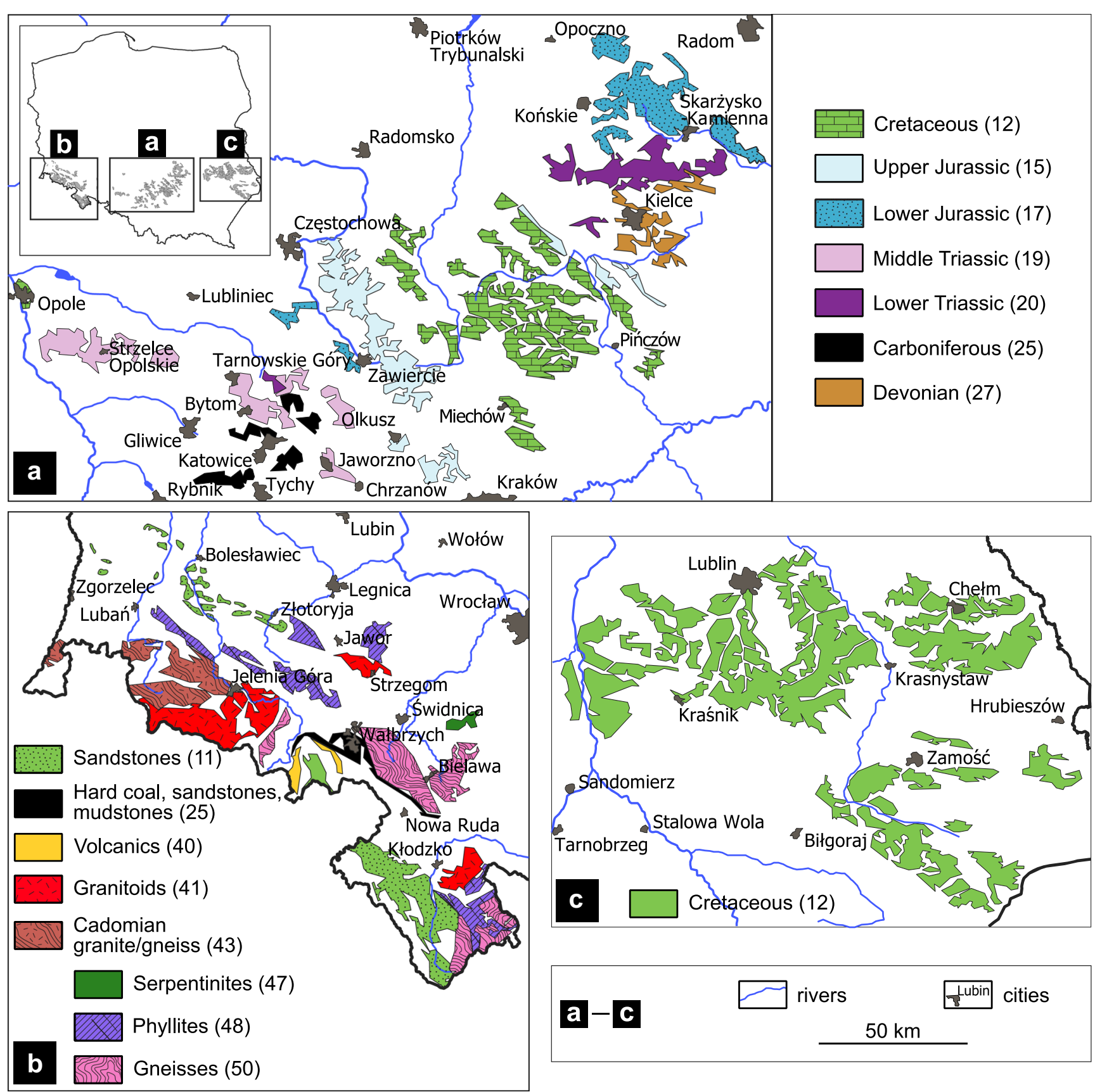

Fig. 6 Exposure of geological units selected in the evaluation process (other than shown in Fig. 5. a Map of the Polish Uplands; the Lublin Upland is excluded. b Sudety Mountains and the Sudetic Foreland. c Lublin Upland

transparent at the preliminary selection stage; the initial database is acquired from the geological map of Poland. However, the list of the most common erratic boulders was assembled based on the author's judgement (i.e. in the direct or "expert" mode), which is subjective. The need for clear preselection criteria was stressed by Reynard et al. (2016); thus the process of selection of rock types from glacial deposits should be clarified in the future.

The number of rock types chosen for the project was tentatively set at 18 . This limit is subjective and depends on the number of the rock types available and the capacity of the project. The method of numerical evaluation of rock types was developed solely for this project and can only be applied in Poland or in countries with comparable forms of nature protection. The use of the method for the evaluation of the geo-education potential of rocks from other areas will require the expressions and weights to be revised.

The parameters considered here do not take into account the perception of rock types by potential geotourists and the amount of advanced professional interpretation necessary to gain insight into geological processes, although the tradition of exploitation for decorative purposes $(B s, D s)$ can serve as 
an approximation of the beauty of the rock. Detailed research on the aesthetic values of the rock types involved in the study is necessary to exclude lithological varieties that are not attractive and/or difficult to recognise by an untrained collector, diminishing the overall satisfaction which depends on the amount of knowledge that the user can acquire autonomously and their ability to grasp the geoscientific concepts related to the rock or geosite (Mikhailenko and Ruban 2019). Geodiversity elements that do not require advanced interpretation facilities should be preferred in the project, as the earlier works point out that it is mostly easy-to-understand or picturesque geomorphological geosites that should be promoted in global geoparks (Chylińska 2019). The visual appearance of the geosite is regarded as an important criterion in the evaluation process (Brilha 2016); the same would apply to in situ geodiversity elements.

Rare rock types that are poorly exposed and/or occur in protected areas (sedimentary and metamorphic rocks of the Tatra Mountains, in particular) and are not suitable for fieldwork received the lowest scores in the evaluation, which represents an advantage of the assessment method employed here. The relatively high number of sedimentary rocks that scored the highest and was used for promotional activities reflects their overall abundance in Poland. The presence of igneous and metamorphic rocks is limited to glacial/ fluvioglacial deposits and the Sudety and Tatra Mountains. Exposures of these rocks in other parts of the country are small and not included on the 1:500,000 scale geological map. The list of rock types selected for the promotional efforts is, therefore, representative of the main geological units in the context of Poland.

\section{Preferences of Potential Geotourists}

The largest number of clicks on the interactive geological map of Poland was recorded for the rock types that outcrop in the areas most interesting for geotourists (the Holy Cross Mountains, Kraków-Częstochowa Upland, the Sudety Mountains, the Carpathians), and their exposures cover significant areas. The same pattern is noted for the number of clicks per unit area: among the most intensively clicked rock types are those outcropping in the tourist regions of Poland. These results confirm that tourist destinations that are traditionally perceived as interesting from a geological point of view attract the most attention. These locations cannot be omitted in educational projects, such as those discussed herein. On the other hand, visitors to the zywaplaneta.pl website are most interested in geosciences, so their fascination in geologically appealing areas could be higher than in the general population.

A significant number of clicks on the interactive map occur outside the most attractive tourist regions of Poland, concentrating in highly urbanised areas (Fig. 7). Three hundred three clicks (3.4\% of the total click number) were made in the centres of the ten largest cities of Poland. This emphasises the importance of urban geology initiatives, which give a wide
Fig. 7 Number of clicks per unit area $\left(100 \mathrm{~km}^{2}\right)$ counted from the interactive geological map of Poland, with locations of ten largest cities of Poland. HCM, Holy Cross Mountains; KCU, Kraków-Częstochowa Upland; SM, Sudety Mountains; TM, Tatra Mountains

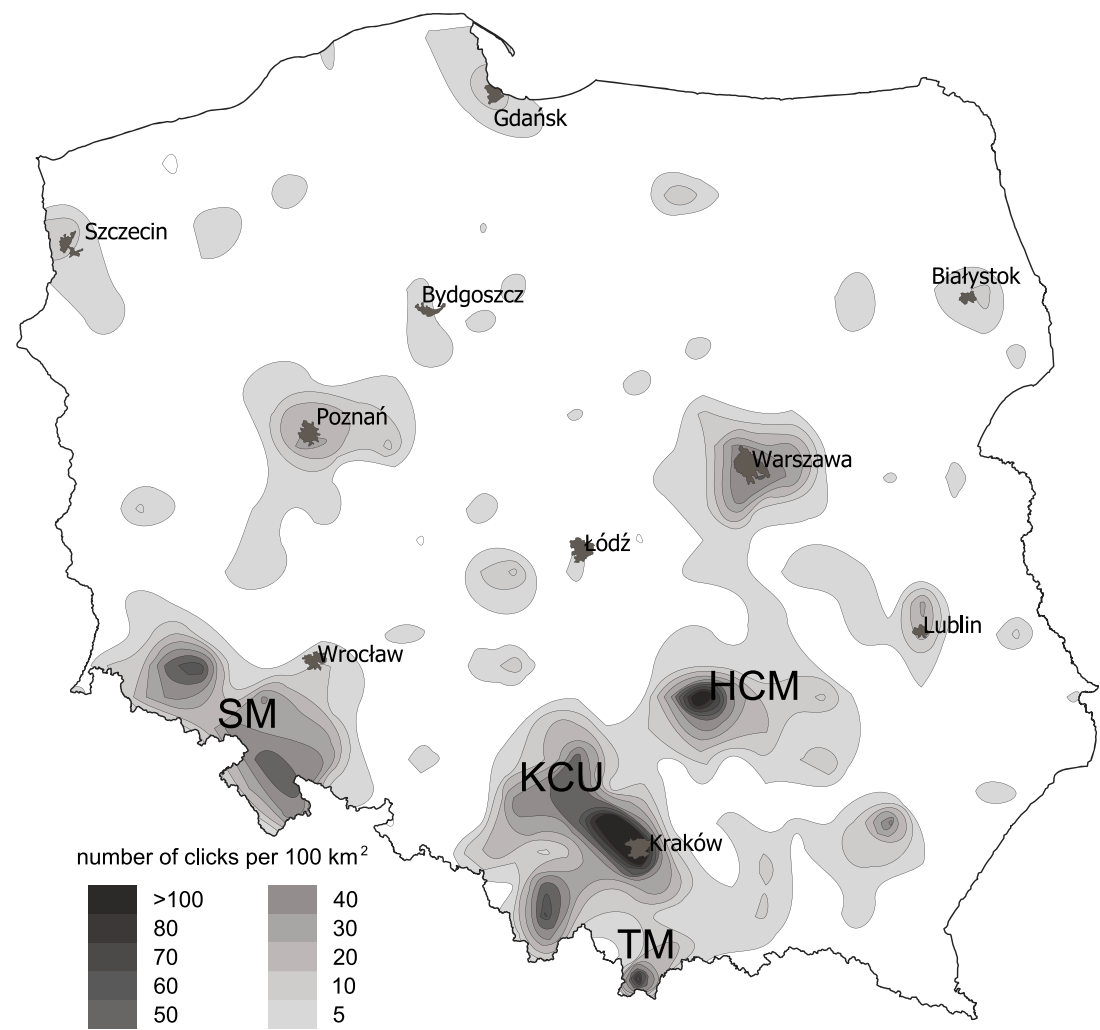


opportunity to study geological features in metropolitan areas (de Wever et al. 2017). However, they should not be limited to communicating scientific information on building and decorative stones, covering instead a broader scope of topics related to rock types that can be found in rare outcrops located in the vicinities of densely populated areas.

\section{Future of the Project}

Future strategies for promoting petrographic geodiversity to the wider public in the area under study may include elements of place-based education (PBE; Semken et al. 2017). The methodology applied here allows the user to study geological features of a small area of interest or place of residence, making use of human connections to places, which can be further expanded into a full PBE curriculum. This would foster a better comprehension and appreciation of the geological value of one's surroundings and have a significant impact on geoconservation and geodiversity education.

More detailed studies of the preferences of potential geotourists are also required. A limited data set is discussed here, but, nevertheless, it misses out the demographic characteristics of the respondents and includes no information on the impact of the project on their further decisions and its potential to stimulate individual fieldwork and interest in geosciences.

Other future improvements include the development of the mobile version of the interactive geological map. The publication of successive digital documents related to the rock types selected in the assessment procedure is also planned, together with workshops held in the Museum of Earth Sciences in Poznan. Download counts for the digital content published online from March 2015 to May 2020 and the number of participants of educational activities reveal the potential for future expansion of the project.

\section{Conclusions}

The ideas discussed in this contribution could encourage amateur geoscientists to independently explore the geological phenomena in their vicinity, fostering the use of sites of geological interest that are not included in geodiversity inventories. The usage of purposely preserved geological sites is replaced by the individual searching and studying outcrops and geodiversity sites, improving field practices and learning through experience, which facilitates the acquisition of knowledge and enhances the understanding of abstract concepts. Cartographic output produced by the project, including an interactive map that combines data from geological and geomorphological maps and places all data on rocks and landforms on a single map, stimulates an independent search and exploration of exposures.
In most cases, local exposures and popular rock types used in the present study do not require any form of protection and can be studied and sampled by amateur collectors without any loss of geodiversity. In the digital assets published in the project, however, the importance of good sampling practices and the significance of possible scientific findings are underlined.

The indexes used here for the measurement of the geoeducational potential of common rock types can be used in countries with different models of nature protection after the expressions and weights are adjusted to local circumstances. Rock types that have the largest outcrops are located outside national parks and reserves and scored the highest during the evaluation. Many of the petrographic geodiversity elements also received a significant number of clicks during the public evaluation, confirming that they are of geoscientific interest to the general public. Most clicks were recorded in areas known for their geological heritage and in densely populated areas, confirming the usefulness of urban geology projects.

Availability of data and material Submitted as Online resources 1 and 2

Code availability Not applicable

Supplementary Information The online version contains supplementary material available at https://doi.org/10.1007/s12371-021-00557-9.

\section{Declarations}

Competing interests The author declares no competing interests.

Open Access This article is licensed under a Creative Commons Attribution 4.0 International License, which permits use, sharing, adaptation, distribution and reproduction in any medium or format, as long as you give appropriate credit to the original author(s) and the source, provide a link to the Creative Commons licence, and indicate if changes were made. The images or other third party material in this article are included in the article's Creative Commons licence, unless indicated otherwise in a credit line to the material. If material is not included in the article's Creative Commons licence and your intended use is not permitted by statutory regulation or exceeds the permitted use, you will need to obtain permission directly from the copyright holder. To view a copy of this licence, visit http://creativecommons.org/licenses/by/4.0/.

\section{References}

Badora K (2014) Spatial system of landscape protection in Poland. Dissertations of Cultural Landspace Commission 23:73-88

Badura J, Przybylski B, Zuchiewicz W (2004) Cainozoic evolution of Lower Silesia, SW Poland: a new interpretation in the light of subCainozoic and sub-Quaternary topography. Acta Geodyn Geomater $1: 7-29$

Blair TC, McPherson JG (1999) Grain-size and textural classification of coarse sedimentary particles. J Sediment Res 69:6-19 
Božić S, Tomić N (2015) Canyons and gorges as potential geotourism destinations in Serbia: comparative analysis from two perspectives general geotourists' and pure geotourists'. Open Geosci 7:531-546

Brilha J (2016) Inventory and quantitative assessment of geosites and geodiversity sites: a review. Geoheritage 8:119-134

Brocx M, Semeniuk V (2007) Geoheritage and geoconservation-history, definition, scope and scale. J R Soc W Aust 90:53-87

Brocx M, Semeniuk V (2019) Building stones can be of geoheritage significance. Geoheritage 11:133-149

Bruschi VM, Cendrero A, Albertos JAC (2011) A statistical approach to the validation and optimisation of geoheritage assessment procedures. Geoheritage 3:131-149

Chylińska D (2019) The role of the picturesque in geotourism and iconic geotourist landscapes. Geoheritage 11:531-543

Czubla P, Gałązka D, Górska M (2006) Eratyki przewodnie w glinach morenowych Polski. Prz Geol 54:245-255

De Lima FF, Brilha JB, Salamuni E (2010) Inventorying geological heritage in large territories: a methodological proposal applied to Brazil. Geoheritage 2:91-99

De Wever P, Baudin F, Pereira D, Cornée A, Egoroff G, Page K (2017) The importance of geosites and heritage stones in cities - a review. Geoheritage 9:561-575

Druguet E, Passchier CW, Pennacchioni G, Carreras J (2013) Geoethical education: a critical issue for geoconservation. Episodes 36:11-18

Elmi C, Simal AG, Winchester GP (2020) Developing a rock garden at Edith J. Carrier Arboretum, Harrisonburg VA (U.S.A.) as a resource for promoting geotourism. Geosci 10:415

Gerliński G, Pieńkowski G, Niedźwiedzki G (2004) Tetrapod track assemblage in the Hettangian of Sołtyków, Poland, and its paleoenvironmental background. Ichnos 11:195-213

Gomes CR, Rocha AF, Ferreira JA, Rola A (2016) Field classes for geosciences education: teachers' concepts and practices. In: Vasconcelos C (ed) Geoscience Education. Springer International Publishing Switzerland, Indoor and Outdoor, pp 73-84

Gordon JE (2019) Geoconservation principles and protected area management. Int J Geoheritage Parks 7:199-210

Górska-Zabielska M (2008) Obszary macierzyste skandynawskich eratyków przewodnich osadów ostatniego zlodowacenia północnozachodniej Polski i północno-wschodnich Niemiec. Geologos 14: 177-194

Górska-Zabielska M, Witkowska K, Pisarska M (2020) The selected erratic boulders in the Świętokrzyskie Province (central Poland) and their potential to promote geotourism. Geoheritage 12:30

Kubalíková L (2013) Geomorphosite assessment for geotourism purposes. Czech J Tour 2:80-104

Marks L, Ber A, Gogołek W, Piotrowska K (2006) Geological map of Poland 1:500 000, with explanatory text. Polish Geological Institute, Warszawa

Migoń P, Pijet-Migoń E (2020) Late Palaeozoic volcanism in central Europe-geoheritage significance and use in geotourism. Geoheritage 12:43

Mikhailenko AV, Ruban DA (2019) Geo-heritage specific visibility as an important parameter in geo-tourism resource evaluation. Geosci 9: 146

Moliner L, Mampel L (2019) The rock garden "Geologist Juan Paricio" (Alcorisa, Maestrazgo Geopark, Spain): an effective example of geosciences popularization. Geoheritage 11:1869-1878

Moutinho A, Almeida Â (2016) The importance of geology as a contribution to the awareness of the cultural heritage as an educational resource. In: Vasconcelos C (ed) Geoscience Education. Springer International Publishing Switzerland, Indoor and Outdoor, pp 85101
Newsome D, Dowling R (2006) The scope and nature of geotourism. In: Dowling RE, Newsome D (eds) Geotourism. Elsevier Butterworth Heinemann, Oxford, pp 3-25

Orion N (1993) A model for the development and implementation of field trips as an integral part of the science curriculum. Sch Sci Math 93: 325-331

Page K (2003) The protection of Jurassic sites and fossils: challenges for global Jurassic science (including a proposed statement on the conservation of palaeontological heritage and stratotypes). Riv Ital Paleontol Stratigr 110:373-379

ProGEO (2011) Conserving our shared geoheritage - a protocol on geoconservation principles, sustainable site use, management, fieldwork, fossil and mineral collecting. ProGEO, Uppsala, $10 \mathrm{pp}$

Reynard E, Fontana G, Kozlik L, Scapozza C (2007) A method for assessing scientific and additional values of geomorphosites. Geogr Helv 62:148-158

Reynard E, Perret A, Bussard J, Grangier L, Martin S (2016) Integrated approach for the inventory and management of geomorphological heritage at the regional scale. Geoheritage 8:43-60

Różycka M, Migoń P (2018) Customer-oriented evaluation of geoheritage - on the example of volcanic geosites in the West Sudetes, SW Poland. Geoheritage 10:23-37

Ruban DA, Kuo I-L (2010) Essentials of geological heritage site (geosite) management: a conceptual assessment of interests and conflicts. Natura Nascosta 41:16-31

Sanz J, Zamalloa T, Maguregi G, Fernandez L, Echevarria I (2020) Educational potential assessment of geodiversity sites: a proposal and a case study in the Basque Country (Spain). Geoheritage 12:23

Semken S, Ward EG, Moosavi S, Chinn PWU (2017) Place-based education in geoscience: theory, research, practice and assessment. J Geosci Educ 65:542-562

Słomka T (2008) Geodiversity of Poland. Prz Geol 56:584-587

Solon J, Borzyszkowski J, Bidłasik M, Richling A, Badora K, Balon J, Brzezińska-Wójcik T, Chabudziński Ł, Dobrowolski R, Grzegorczyk I, Jodłowski M, Kistowski M, Kot R, Krąż P, Lechnio J, Macias A, Majchrowska A, Malinowska E, Migoń P, Myga-Piątek U, Nita J, Papińska E, Rodzik J, Strzyż M, Terpiłowski S, Ziaja W (2018) Physico-geographical mesoregions of Poland: verification and adjustment of boundaries on the basis of contemporary spatial data. Geogr Pol 91:143-170

Štrba L' (2019) Analysis of criteria affecting geosite visits by general public: a case of Slovak (geo)tourists. Geoheritage 11:291-300

Tan E, So H-J (2019) Role of environmental interaction in interdisciplinary thinking: from knowledge resources perspectives. J Environ Educ 50:113-130

Tomić N, Božić S (2014) A modified geosite assessment model (MGAM) and its application on the Lazar Canyon area (Serbia). Int J Environ Res 8:1041-1052

Van Loon AJ (2008) Geological education of the future. Earth Sci Rev $86: 247-254$

Waldron JWF, Locock AJ, Pujadas-Botey A (2016) Building an outdoor classroom for field geology: the Geoscience Garden. J Geosci Educ 64:215-230

Warowna J, Migoń P, Kołodyńska-Gawrysiak R, Kiebała A, Zgłobicki W (2013) Geomorphosites of Poland - the role played by the Central Register of Geosites. Landform Anal 22:117-124

Wysession ME, LaDue N, Budd DA, Campbell K, Conklin M, Kappel E, Lewis G, Raynolds R, Ridky RW, Ross RM, Taber J, Tewksbury B, Tuddenham P (2012) Developing and applying a set of Earth science literacy principles. J Geosci Educ 60:95-99 